\title{
Article \\ Climate Change Influences Basidiome Emergence of Leaf-Cutting Ant Cultivars
}

\author{
Rodolfo Bizarria, Jr. *, Pepijn W. Kooij * and Andre Rodrigues * \\ Department of General and Applied Biology, São Paulo State University (UNESP), Rio Claro 13506-900, SP, Brazil \\ * Correspondence: rodolfo.bizarria@unesp.br (R.B.J.); p.kooij@unesp.br (P.W.K.); \\ andre.rodrigues@unesp.br (A.R.)
}

check for updates

Citation: Bizarria, R., Jr.; Kooij, P.W.; Rodrigues, A. Climate Change Influences Basidiome Emergence of Leaf-Cutting Ant Cultivars. J. Fungi 2021, 7, 912. https://doi.org/ 10.3390/jof7110912

Academic Editors:

Aristóteles Góes-Neto, Elisandro

Ricardo Drechsler-Santos, Diogo

Henrique Costa-Rezende,

João Araújo and József Geml

Received: 12 August 2021

Accepted: 21 October 2021

Published: 27 October 2021

Publisher's Note: MDPI stays neutral with regard to jurisdictional claims in published maps and institutional affiliations.

Copyright: (c) 2021 by the authors. Licensee MDPI, Basel, Switzerland. This article is an open access article distributed under the terms and conditions of the Creative Commons Attribution (CC BY) license (https:// creativecommons.org/licenses/by/ $4.0 /)$.

\begin{abstract}
Maintaining symbiosis homeostasis is essential for mutualistic partners. Leaf-cutting ants evolved a long-term symbiotic mutualism with fungal cultivars for nourishment while using vertical asexual transmission across generations. Despite the ants' efforts to suppress fungal sexual reproduction, scattered occurrences of cultivar basidiomes have been reported. Here, we review the literature for basidiome occurrences and associated climate data. We hypothesized that more basidiome events could be expected in scenarios with an increase in temperature and precipitation. Our field observations and climate data analyses indeed suggest that Acromyrmex coronatus colonies are prone to basidiome occurrences in warmer and wetter seasons. Even though our study partly depended on historical records, occurrences have increased, correlating with climate change. A nest architecture with low (or even the lack of) insulation might be the cause of this phenomenon. The nature of basidiome occurrences in the A. coronatus-fungus mutualism can be useful to elucidate how resilient mutualistic symbioses are in light of climate change scenarios.
\end{abstract}

Keywords: fungal sexual reproduction; fungiculture; fungus-growing ants; mushroom phenology; nest architecture

\section{Introduction}

Fungiculture evolved in fungus-growing ants about 55-65 million years ago [1-3]. To maintain symbiosis homeostasis, ants provide suitable environmental conditions to nurture their fungal partners [4-7]. Leaf-cutting ants in genera Acromyrmex Mayr, 1865; Amoimyrmex Cristiano, Cardoso and Sandoval, 2020 [8]; and Atta Fabricius, 1804, are notable as dominant herbivores in the Neotropics [7], due to the foraging of a considerable amount of leaves as the substrate for their basidiomycete cultivar (Agaricales: Agaricaceae: Leucoagaricus gongylophorus (Möller) Singer (1986)) [9]. In addition to foraging, leaf-cutting ants are also ecosystem engineers, modifying the environment and performing key ecosystem services [7,10-12] such as nutrient cycling [13], seed dispersal and germination [14], and increasing soil fertility and plant growth [15].

The fungal partner of leaf-cutting ants is vertically transmitted as mycelium across generations carried inside the infrabuccal pocket of foundress queens [16-18]. Despite the long-term history of clonal transmission, singular field occurrences of basidiomes were reported in this mutualism [19], mostly on shallow nests (Tables 1 and S1) [20-22]. Asexual transmission performed by leaf-cutting ants contrasts with the preferred sexual reproduction of the fungal partners [19], which may explain the efforts of ants to promptly remove the mushrooms [23-26], characterizing a conflict of interest between partners over reproduction [19]. Basidiome formation was previously suggested to be regulated by environmental factors in this mutualism, such as temperature and humidity, in laboratory colonies of Acromyrmex crassispinus (Forel, 1909) [23], and nest ventilation for field colonies of the leaf-cutting ant Atta cephalotes (Linnaeus, 1758) [21]. 
Table 1. Field occurrences of basidiomes in leaf-cutting ant nests. Data reviewed in the literature were compiled with new occurrence reports since the publication by Mueller (2002) [19]. A full version of the table is available in Table S1.

\begin{tabular}{|c|c|c|c|}
\hline Ant Species & Fungal Species & Occurrence Data & References \\
\hline Acromyrmex aspersus & Leucoagaricus gongylophorus & $\begin{array}{l}\text { Basidiomes found on } 29 \text { November } \\
1995 \text { in an active nest in a native forest } \\
\text { in Santa Cruz do Sul-RS (Rio } \\
\text { Pardinho), Brazil. }\end{array}$ & [27] \\
\hline Acromyrmex coronatus & Leucoagaricus gongylophorus & $\begin{array}{l}\text { Basidiomes observed on } 23 \text { March } \\
2006, \\
\text { in Rio Claro-SP (UNESP Campus), } \\
\text { Brazil. }\end{array}$ & $\begin{array}{l}\text { Bacci M. (personal } \\
\text { communication) }\end{array}$ \\
\hline Acromyrmex coronatus & Leucoagaricus gongylophorus & $\begin{array}{l}\text { Basidiomes observed on } 5 \text { and } 27 \\
\text { January } 2018 \text { in Rio Claro-SP, Brazil } \\
\text { (Colony ID: BLS170701-01). }\end{array}$ & This study \\
\hline Acromyrmex coronatus & Leucoagaricus gongylophorus & $\begin{array}{l}\text { Basidiomes observed on } 5 \text { April and } \\
27 \text { November 2018, } 28 \text { January 2019, } \\
10 \text { February 2020, in Rio Claro-SP, } \\
\text { Brazil (Colony ID: RB181203-01). One } \\
\text { specimen is deposited in the } \\
\text { herbarium of the Federal University of } \\
\text { Santa Catarina \# FLOR0068416). }\end{array}$ & This study \\
\hline Acromyrmex coronatus & Leucoagaricus gongylophorus & $\begin{array}{l}\text { Basidiome observed on } 29 \text { December } \\
2019 \text { in Mogi-Guaçu-SP, Brazil (colony } \\
\text { ID: RB200104-01). }\end{array}$ & This study \\
\hline Acromyrmex coronatus & Leucoagaricus gongylophorus & $\begin{array}{l}\text { Basidiomes observed on } 2 \text { and } 10 \\
\text { January 2020, } 5 \text { and } 7 \text { February, } 12 \\
\text { November, and } 13 \text { and } 18 \text { December } \\
2020 \text { in Rio Claro-SP, Brazil (Colony } \\
\text { ID: RB190909-01). }\end{array}$ & This study \\
\hline Acromyrmex coronatus & Leucoagaricus gongylophorus & $\begin{array}{l}\text { Basidiome observed on } 4 \text { January } 2020 \\
\text { in Mogi-Guaçu-SP, Brazil (Colony ID: } \\
\text { RB200104-03). }\end{array}$ & This study \\
\hline Acromyrmex coronatus & Leucoagaricus gongylophorus & $\begin{array}{l}\text { Basidiome observed on } 21 \text { February } \\
\text { 2020, in Rio Claro-SP, Brazil (Colony } \\
\text { ID: RB200507-03). }\end{array}$ & This study \\
\hline Acromyrmex crassispinus & $\begin{array}{l}\text { Rozites gongylophora } \\
\text { (=Leucoagaricus gongylophorus) }\end{array}$ & $\begin{array}{l}\text { As mentioned in Gonçalves (1961, } \\
\text { page 117) “Luederwaldt } 1926 \\
\text { observed basidiomes on nests of } A \text {. } \\
\text { crassispinus (cited as } A \text {. nigra). }\end{array}$ & {$[19,28,29]$} \\
\hline Acromyrmex disciger & $\begin{array}{l}\text { Leucocoprinus gongylophorus } \\
\text { (=Leucoagaricus gongylophorus) }\end{array}$ & $\begin{array}{l}\text { Basidiomes observed in November } \\
\text { 1891, } 19 \text { February, and } 17 \text { and } 30 \\
\text { March } 1892 \text { in Blumenau-SC, Brazil. }\end{array}$ & {$[19,20,30]$} \\
\hline Acromyrmex hispidus fallax & $\begin{array}{l}\text { Rozites gongylophora } \\
\text { (=Leucoagaricus gongylophorus) }\end{array}$ & $\begin{array}{l}\text { Observation from } 11 \text { November } 1944 \\
\text { in Curitiba-PR, Brazil (see page 143). }\end{array}$ & {$[19,28]$} \\
\hline Acromyrmex hispidus fallax & Leucoagaricus gongylophorus & $\begin{array}{l}\text { Last week of February } 1996 \text { (dozen of } \\
\text { basidiomes) and April (ten } \\
\text { basidiomes) in Rio Claro-SP, Brazil. } \\
\text { Colony found under a peach tree. }\end{array}$ & {$[19,22]$} \\
\hline Atta cephalotes & Unidentified & No data/not sure & {$[19,31]$} \\
\hline Atta cephalotes & Unidentified & $\begin{array}{l}\text { Lelydorp, } 20 \mathrm{~km} \text { near Paramaribo, } \\
\text { Suriname. }\end{array}$ & {$[19,32,33]$} \\
\hline Atta cephalotes & $\begin{array}{l}\text { Rozites gongylophora } \\
\text { (=Leucoagaricus gongylophorus) }\end{array}$ & $\begin{array}{l}8 \text { and } 9 \text { November } 1939 \text { in Paramaribo, } \\
\text { Suriname (see pages 253-254, and } \\
\text { 258-266). }\end{array}$ & {$[19,21]$} \\
\hline Atta cephalotes & $\begin{array}{l}\text { Rozites gongylophora } \\
\text { (=Leucoagaricus gongylophorus) }\end{array}$ & $\begin{array}{l}13 \text { January 1940, in Paramaribo, } \\
\text { Suriname (see page 260). }\end{array}$ & {$[19,21]$} \\
\hline
\end{tabular}


Table 1. Cont.

\begin{tabular}{|c|c|c|c|}
\hline Ant Species & Fungal Species & Occurrence Data & References \\
\hline Atta colombica & Leucocoprinus cf. gongylophorus & No data/not sure & $\begin{array}{l}\text { Collection PA-236, U.G. Mueller, } \\
\text { unpublished data }\end{array}$ \\
\hline Not informed & Rozites gongylophora & Basidiome observed on 29 May 1957. & $\begin{array}{l}\text { gbif.org/occurrence/2464956731, } \\
\text { last accessed on } 25 \text { June } 2021\end{array}$ \\
\hline $\begin{array}{l}\text { We assumed Acromyrmex sp. } \\
\text { on the basis of the collector's } \\
\text { ant-colony descriptions }\end{array}$ & Leucoagaricus gongylophorus & $\begin{array}{l}\text { Basidiome observed on } 22 \text { December } \\
2010 \text { in Brasília-DF, Brazil. Sh Jardim } \\
\text { Botânico/Condomínio Quintas Bela } \\
\text { Vista Conjunto e-Jardim Botânico, } \\
\text { Brasília-DF, 70297-400, Brasil } \\
\text { (Coordinates: } 15.9 \text { S and } 47.8 \mathrm{~W} \text { ). }\end{array}$ & $\begin{array}{l}\text { gbif.org/occurrence/1986496332, } \\
\text { last accessed on } 25 \text { June } 2021\end{array}$ \\
\hline $\begin{array}{l}\text { We assumed Acromyrmex sp. } \\
\text { on the basis of collector's } \\
\text { ant-colony descriptions }\end{array}$ & Leucoagaricus gongylophorus & $\begin{array}{l}\text { Basidiome observed on } 11 \text { November } \\
2017 \text { in Parque Nacional da Serra dos } \\
\text { Órgãos-Parnaso, Teresópolis-RJ, } \\
\text { Brazil. }\end{array}$ & $\begin{array}{l}\text { Heisecke C., Duque J. and } \\
\text { Venegas M. (personal } \\
\text { communication) }\end{array}$ \\
\hline
\end{tabular}

Symbioses are responsive to biotic and abiotic components of ecosystems [34-37]. Here, to investigate the influence of climatic parameters in the mushroom phenology of cultivars of leaf-cutting ants, we reviewed environmental conditions for nests with confirmed events of basidiomes in previous reports. Furthermore, we added new reports of recent observations from nests of leaf-cutting ant Acromyrmex coronatus (Fabricius, 1804) in Brazil. On the basis of previous mushroom phenology observations [38,39], we hypothesized that, if basidiome occurrences are tied with climate change, more basidiome events are expected with increased temperature and precipitation. Alternatively, basidiome occurrences could be linked with only one of these factors or simply be random events. The nest architecture of $A$. coronatus in tree forks, exposure to warmer and wetter seasons, and the observed fluctuations in temperature and precipitation suggest that climate change increased basidiome occurrences. The nature of these occurrences can be useful to understand how symbiotic systems could be resilient to environmental disturbances, especially in light of climate change scenarios.

\section{Material and Methods}

To establish the current panorama of basidiome occurrences in leaf-cutting ant-fungus mutualism, we reviewed field occurrences since Mueller (2002) [19], adding new reports scattered across the literature and in the Global Biodiversity Information Facility database (GBIF; Tables 1 and S1) [40,41]. In addition, basidiomes of L. gongylophorus were observed emerging from colonies of A. coronatus throughout 2018-2021 in Rio Claro, State of São Paulo, Brazil (Tables 1 and S1), and were collected and transferred to the laboratory for mycological evaluation (morphological and molecular analyses, and basidiospore germination assays). Specimens were dried in a food dehydrator, and a representative specimen was deposited at FLOR (Herbarium of the Federal University of Santa Catarina, Department of Botany, Center for Biological Sciences, Florianópolis, Brazil, voucher \#FLOR0068416). Basidiospores were collected by spore print from mature basidiomes, i.e., laying the cap directly over glass slides (disinfected with 70\% ethanol) and keeping this at room temperature overnight. Collected basidiospores were then picked up using a sterile inoculation loop, suspended in saline solution $(0.85 \% \mathrm{NaCl})$, followed by serial dilution and inoculation on growth media. Alternatively, basidiospores were collected by fixing a piece of the cap with the gills facing downwards on the lid of Petri plates with an agar fragment, allowing for basidiospores to drop on the culture medium for $24 \mathrm{~h}$ at room temperature. In both methods, Potato Dextrose Agar (PDA 3.9\%, NEOGENE ${ }^{\circledR}$ Culture Media, Lasing, MI, USA) and Yeast Dextrose Agar (YPD: $1 \%$ yeast extract, $2 \%$ peptone, $2 \%$ glucose, and $1.5 \%$ Agar) supplemented with $150 \mathrm{mg} \mathrm{mL}^{-1}$ of chloramphenicol (Sigma-Aldrich; St. Louis, MO, USA) were used as culture media, and plates were incubated at $25^{\circ} \mathrm{C}$ in darkness. 
Fungal genomic DNA was extracted following Lacerda et al. (2018) [42] with modifications. Fungal samples were mechanically broken with glass beads (425-600 $\mu \mathrm{m}$ in diameter; Sigma-Aldrich, St. Louis, MO, USA) in $500 \mu \mathrm{L}$ sterile lysis buffer (Tris $100 \mathrm{mM}$, EDTA $10 \mathrm{mM}$, SDS $2 \%$; pH 8). Then, $5 \mu \mathrm{L}$ of Proteinase $\mathrm{K}(20 \mathrm{mg} / \mathrm{mL})$ was added, and samples were incubated at $65^{\circ} \mathrm{C}$ for $30 \mathrm{~min}$. Afterwards, $140 \mu \mathrm{L}$ of $5 \mathrm{M} \mathrm{NaCl}$ and $64 \mu \mathrm{L}$ of $10 \% \mathrm{CTAB}$ were added followed by incubation at $65^{\circ} \mathrm{C}$ for $60 \mathrm{~min}$. Tubes were centrifuged at 10,000 rpm (Eppendorf microcentrifuge, 5424) for $30 \mathrm{~s}$, and $600 \mu \mathrm{L}$ of chloroform:isoamyl alcohol (24:1) solution was added followed by centrifugation at 12,000 rpm for $10 \mathrm{~min}$. The supernatant was collected and transferred to sterile $1.5 \mathrm{~mL}$ tubes. Then, $300 \mu \mathrm{L}$ of ice-cold absolute isopropanol and $50 \mu \mathrm{L}$ of $3 \mathrm{M}$ sodium acetate $\mathrm{pH} 5.2$ were added. The suspensions were then centrifuged at 10,000 rpm for $10 \mathrm{~min}$, removed by single inversion, and washed with $600 \mu \mathrm{L}$ of $70 \%$ ethanol. For ethanol removal, the suspensions were centrifuged at $10,000 \mathrm{rpm}$ for $10 \mathrm{~min}$, followed by a single inversion procedure. After ethanol evaporation, $30 \mu \mathrm{L}$ of Tris EDTA buffer (10 mM Tris; $1 \mathrm{mM}$ EDTA) was added.

For polymerase chain reaction (PCR) amplification, DNA was diluted $(1: 10 v / v)$ in ultrapure sterile water, and PCR reactions were performed in $25 \mu \mathrm{L}$ reaction volume. The internal transcribed spacer (ITS) region and a fragment of the large subunit (LSU) ribosomal DNA gene were amplified with primer pairs ITS5-ITS4 [43] and LR0R-LR5 [44, 45], respectively. PCRs were performed with $4 \mu \mathrm{L}$ of dNTPs, $5 \mu \mathrm{L}$ of buffer $5 \times, 2 \mu \mathrm{L}$ of $25 \mathrm{mM} \mathrm{MgCl} 2,1 \mu \mathrm{L}$ of $10 \mu \mathrm{M}$ forward primer, $1 \mu \mathrm{L}$ of $10 \mu \mathrm{M}$ reverse primer, $1 \mu \mathrm{L}$ of bovine serum albumin (BSA; mg mL ${ }^{-1}$ ), $8.8 \mu \mathrm{L}$ of ultrapure sterile water, $0.2 \mu \mathrm{L}$ of

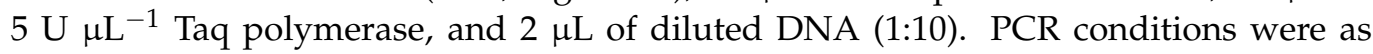
follows: $94{ }^{\circ} \mathrm{C} / 3 \mathrm{~min}, 35$ cycles of $94{ }^{\circ} \mathrm{C} / 1 \mathrm{~min}, 55^{\circ} \mathrm{C} / 1 \mathrm{~min}$, and $72{ }^{\circ} \mathrm{C} / 2 \mathrm{~min}$. Amplicon purification was performed with Wizard ${ }^{\mathrm{TM}}$ SV Gel and PCR Clean-Up System (Promega, Madison, WI, USA), and sequencing reaction was performed using BigDye ${ }^{\circledR}$ Terminator v. 3.1 Cycle Sequencing Kit (Thermo Fisher Scientific, Waltham, MA, USA), according to the manufacturer's protocols. Sanger sequenced amplicons were injected in ABI 3500 Series Genetic Analyzer (Thermo Fisher Scientific, Waltham, MA, USA). Forward and reverse sequences were edited and assembled in Bioedit v. 7.0.0 [46], and then compared with sequences available in the NCBI-GenBank database with BLASTn.

For each reported basidiome occurrence, we surveyed the respective climate data and information regarding nest architecture, colony health, and ant behavior. Climate data were collected from different databases: Agrometeorological Monitoring SystemAgritempo (https:/ / www.agritempo.gov.br/agritempo/index.jsp; data accessed on 13 April 2021), the Meteorological Station at the Center for Environmental Analysis and Planning (CEAPLA; data accessed on 7 April 2020) in Rio Claro, and World Bank Data (http:/ / climateknowledgeportal.worldbank.org/; data accessed on 28 August 2020) for historical data for Rio Claro. To evaluate the influence of climatic fluctuation on basidiome emergence, occurrence counts were compared with the average temperatures (minimal, maximal, and mean) by month and the respective accumulated precipitation (in $\mathrm{mm}$ ). Analyzes were performed with data for the last six months interval considering the month of basidiome occurrence. Since month interval data did not show homogeneity of variances (Bartlett test, $p<0.05$; Table S2), we applied Kruskal-Wallis analysis, followed by MannWhitney $\mathrm{U}$ tests with Benjamini-Hochberg adjustment of $p$ values, both analyses with an alpha threshold of 0.05 . Descriptive statistics were performed to explore the effects of climatic variables on the number of basidiomes, by comparing occurrences with anomalies of temperature and precipitation for each period. Partial least squares (PLS) regression coefficients were estimated for each parameter to describe the interaction between predictor (temperature and precipitation) and response variables (number of basidiomes for each occurrence). Variable importance in projection (VIP) scores were estimated to analyze the relative importance of each variable. VIP scores higher than 1 were considered to be the most relevant predictors. Analyses were conducted in RStudio v. 1.4.1717 [47] using R v. 4.1.0 [48] with packages ggplot2 [49] and mdatools [50]. 


\section{Results}

We recorded a total of 17 occurrences in Rio Claro: 14 new occurrences in 20182020 from 6 A. coronatus nests (Figure 1A-D), 1 occurrence in 2006 from 1 A. coronatus nest, and 2 occurrences in 1996 from 1 Acromyrmex hispidus fallax Santschi, 1925 nest (Tables 1 and S1). Colonies in which we detected basidiomes remained active and foraging for plant substrate (Tables 1 and S1). Ants were cutting pieces of the mature basidiomes after cap opening (Figure 1F) and eventually deformed basidiomes, which were then ignored. We only recorded basidiomes emerging from nests constructed in tree forks by $A$. coronatus (Figure 1A), contrasting with previous observations on shallow or young nests of other leaf-cutting ant species (Table 1). Culturing assays showed that basidiospores of L. gongylophorus were viable and able to germinate (sequence accessions: MZ620731MZ620732 for ITS and MZ618880-MZ618881 for LSU, Table S1), and the resulting mycelium was able to form gongylidia (i.e., specialized hyphal tip swellings of the fungus cultivated by leaf-cutting ants, Figure 2). Blastn results for these showed over $99 \%$ identity, $97 \%$ query cover, and an E-value of 0.0 with cultures obtained from the fungus garden of Acromyrmex coronatus (nest ID: BLS170701-01; reference accessions: MN473881 and MN473139).

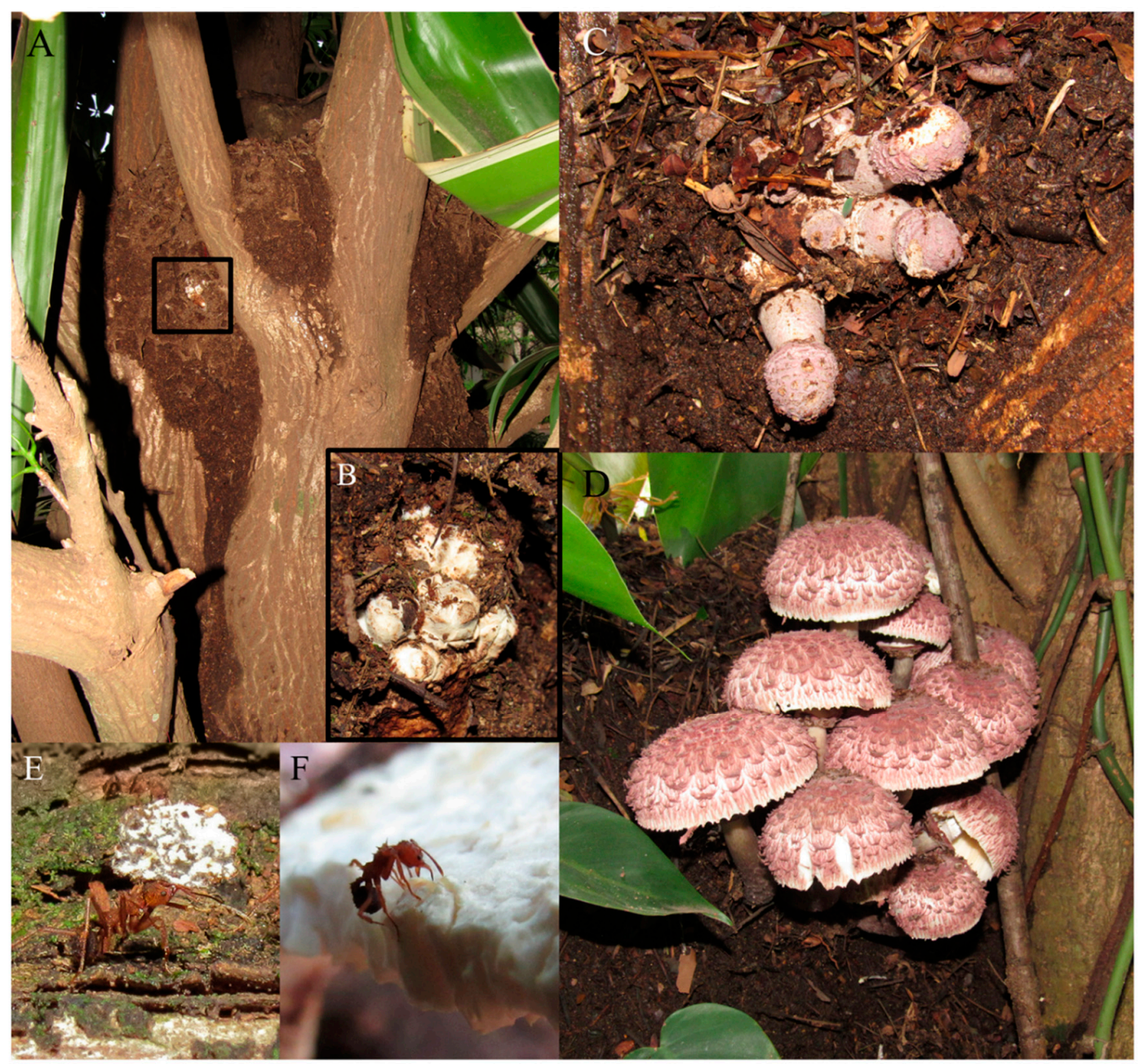

Figure 1. Basidiome occurrence in Acromyrmex coronatus nest in Rio Claro, State of São Paulo, Brazil. (A,B) Basidiome primordia in a nest located in a tree fork. (C,D) Emerged basidiomes. (E) Garden transfer by an A. coronatus worker (see also Supplementary Materials Video S2 for video). (F) A. coronatus worker attempting to cut parts of the basidiome.

Basidiomes were more frequent during hot and rainy seasons (Figure $3 \mathrm{~A}$ ), from November to April. At the start of these periods, ant workers were carrying pieces of their fungus gardens and pupae (Figure 1E), moving them from underground nests to 
tree fork nests, with protective behavior during the garden transferring, i.e., ant workers guarding the route against invasions by other ants (Supplementary Materials Video S2). PLS regression analysis indicated that (lower) precipitation preceding the month of occurrence of basidiomes can be used to predict the number of basidiomes (fourth month, regression coefficients $=1.3450 \pm 0.60, \mathrm{t}=2.19, p=0.044, \mathrm{df}=16$; Figure 3B and Table S3). VIP scores also estimated the importance of precipitation (Table S3), with the highest scores being $1.82,1.42$, and 1.26 obtained for the fourth, the first, and the second month before basidiome occurrences, respectively. With respect to temperature, the scores mainly indicate the highest influence of two months before the occurrences for the number of observed basidiomes (Table S3). Analysis of the last six months before occurrence indicates climate similarities between the months closer to the occurrence in contrast to those further away, which registered lower temperatures (Figure 2C-E; Table S4).

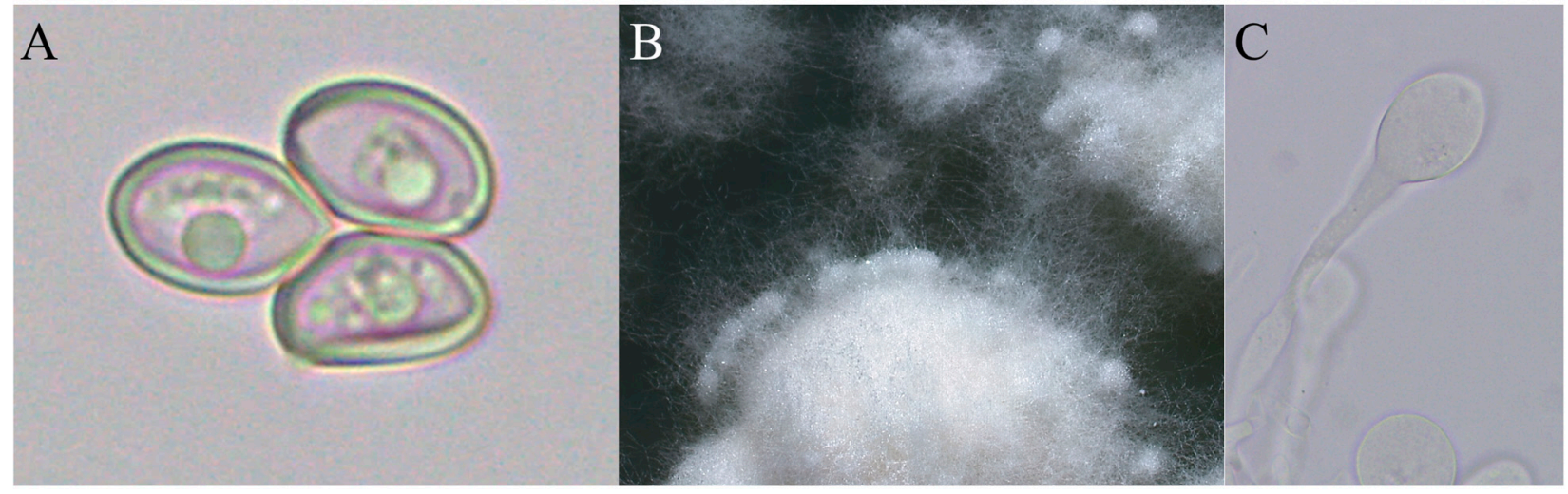

Figure 2. Leucoagaricus gongylophorus cultured from basidiospores. (A) Basidiospores obtained from a basidiome collected on 21 February 2020 in Rio Claro-SP, Brazil (Colony ID: RB200507-03). (B) Fungal mycelium on potato dextrose agar medium after incubating for 30 days at $25{ }^{\circ} \mathrm{C}$ showing typical growth pattern for L. gongylophorus with staphylae (clusters of gongylidia) at the edge. (C) Gongylidia (i.e., specialized hyphal tip swellings) found in the cultured mycelium.
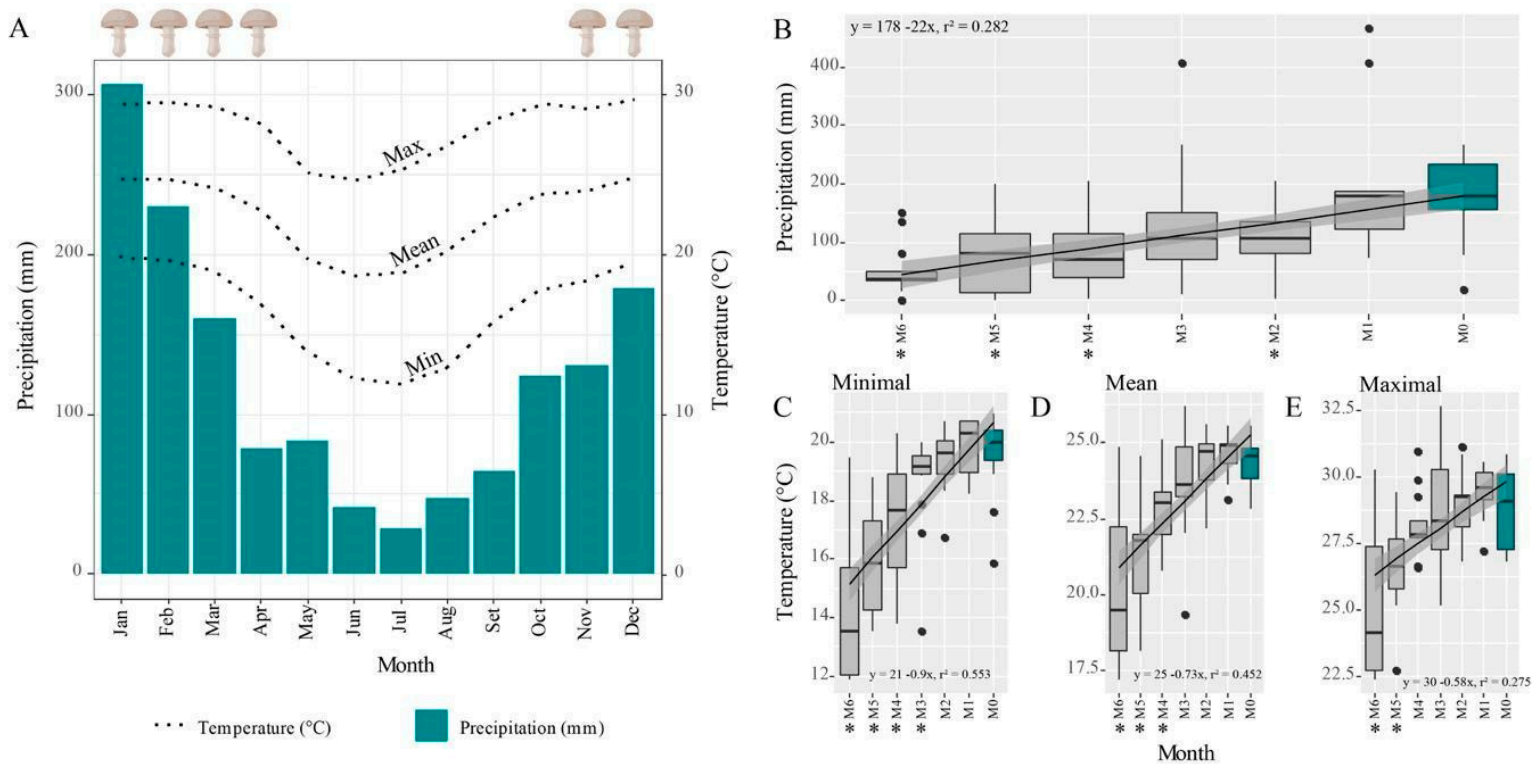

Figure 3. Basidiomes were more frequent during warm and wet seasons. (A) Annual climate panorama (1994-2021) of Rio Claro (State of São Paulo, Brazil) with basidiome occurrences from November to April. (B-E) Six-month interval of climatic data between occurrences (in blue) and months preceding them. Overall, no differences were found between the two months preceding the occurrences (see details of analysis in Table S4), which followed the periods with increased temperature and precipitation. Asterisks indicate statistical differences for the Mann-Whitney U test between the previous months and the month of basidiome occurrence. 


\section{Discussion}

Leaf-cutting ants originated about 19 million years ago [1], establishing a long-term fungal asexual propagation, with limited genetic exchange between cultivar and free-living fungi from natural reservoirs [51]. The potential side effects of long-term clonal transmission [52] and rare occurrences of basidiomes have led to a historical assumption of sexual incompetence of fungal cultivars [19]. However, basidiome occurrences were reported for several leaf-cutting ant species [19] (Tables 1 and S1), suggesting that these occurrences may be more frequent than what was previously thought. Here, we recorded several basidiome occurrences on active $A$. coronatus nests constructed in tree forks. Occurrences were frequent during hot and rainy seasons, mainly after dry seasons.

The sexual reproduction of fungal cultivars is a considerable investment that contrasts with the efforts performed by ants on fungal clonal transmission [19], mainly with the production and release of viable basidiospores. This assumption was supported by observations of attempts by leaf-cutting ants to rapidly remove fungal sexual structures [23-26], suppressing the primordial basidiomes or even cutting away the gills with basidiospores (Figure 1F). Since the pioneering study of Möller (1893), basidiomes have not been confirmed to produce viable basidiospores, as shown by repeated failed attempts of basidiospore germination $[23,25,26]$. Here, a considerable amount of basidiospores were sampled from basidiomes emerging from $A$. coronatus colonies and culturing attempts confirmed viability, supporting the previous observations by Möller (1893) [20]. The implications of fungal basidiospore viability and dispersion probability, and the differences in cultivar growth vigor (i.e., morphologies) from obtained cultures should be further investigated.

Previous occurrences of basidiomes in the leaf-cutting ant-fungus mutualism were recorded from shallow nests $[20,22]$ or from colonies of ant species that build shallow nests (Tables 1 and S1). In contrast to deep underground nests, shallow nests are more exposed to climatic fluctuations due to a lack of insulation of soil layers or plant material (leaf fragments, twigs, etc.), which may explain why most of the field occurrences were recorded from Acromyrmex colonies, since this genus generally creates more shallow nests [19]. Acromyrmex coronatus shows particular plasticity of nest architecture [28], building deep or shallow belowground nests and nests in tree forks. Basidiomes were only observed on A. coronatus nests in trees, which are more likely to be exposed to climatic fluctuations and nest ventilation than belowground nests that are able to maintain a more stable environment [17]. Acromyrmex coronatus workers were also observed moving and carrying pieces of fungus garden at the beginning of the rain seasons (Figure 1E, Supplementary Materials Video S2) despite the risk of garden contamination and drying, which would eventually lead to garden loss. These findings, together with the basidiome occurrences, lead to a seasonal influence on the $A$. coronatus mutualism, mainly through warmer and wetter seasons, and in particular by increasing precipitation in the months before the occurrences.

Climatic effects on fungal basidiomes were also reported in other biological systems, such as in the mutualism between fungus-growing termites and Termitomyces fungi [53], mycorrhizal fungi (e.g., Tricholoma matsutake and Tuber spp.) [38,39,54], and epigeous fungi occurring in forest ecosystems $[55,56]$. The seasonal influence on the A. coronatus-fungus mutualism might increase the basidiome occurrences, which supports our hypothesis of more basidiome events with increased temperature and precipitation. However, further research is necessary to fully reject the alternative hypothesis, which considers a stochastic nature for these events. The influence of climate change on basidiome occurrences might be intensified by the nest architecture and should be further investigated for $A$. coronatus, similar to research for A. ambiguus and A. heyeri [4,5]. Although climatic data here were obtained from different meteorological field stations and not simultaneously measured across all sampling locations, the general basidiome occurrence profiles were similar, and observed in warmer and wetter seasons. The influence of specific parameters that modulate the occurrence and the number of basidiomes should also be further investigated, to avoid data bias. Similarly, the reasons behind the abundance of recent field observations in 
contrast with the rarity of such reports should be carefully investigated in light of climate disturbances. This scenario advances our knowledge on fungus-growing ants ecology and provides a symbiotic model system to study responses to climate disturbances, which are expected to impact biodiversity and ecosystems $[57,58]$.

\section{Conclusions}

Using field observations of $A$. coronatus colonies combined with climate data analyses, we showed that basidiome occurrences in colonies of this leaf-cutting ant increase during the warmer and wetter seasons. The nest architecture of $A$. coronatus colonies with likely low insulation might be the cause of this phenomenon. Furthermore, these events are intensified considering the current climate change scenarios. Although our study partly relies on historical records of basidiomes in the attine ant mutualism, our observations contrast with the rarity of this phenomenon, and further investigation is necessary in light of climate change and the stability of this mutualism.

Supplementary Materials: The following are available online at https:/ / www.mdpi.com/article/10 .3390/jof7110912/s1. Figure S1: Historical climate data of Rio Claro obtained from World Bank Data (http:/ / climateknowledgeportal.worldbank.org/; last accessed on 28 August 2020); Table S1: Field occurrences of basidiomes in leaf-cutting ant nests; Table S2: Results from Bartlett test of homogeneity of variances analysis; Table S3: Results from PLS analysis and corresponding VIP scores; Table S4: Results from Kruskal-Wallis analysis; Video S1: Acromyrmex coronatus ants transfer fungus gardens from belowground nests to nests in tree forks; Video S2: Acromyrmex coronatus ants transferring fungus gardens with protective behavior against Camponotus sp.

Author Contributions: R.B.J., field observations; R.B.J. and P.W.K., data analysis. A.R. drafted the manuscript. All authors have read and agreed to the published version of the manuscript.

Funding: The study was supported by Fundação de Amparo à Pesquisa do Estado de São Paulo (FAPESP)" for financial support [grants \#2019/03746-0 and \#2019/24412-2]. The study was also supported by the "Coordenação de Aperfeiçoamento de Pessoal de Nível Superior-Brazil (CAPES)" Financial Code 001. The contribution to this paper by PK was possible thanks to the scholarship granted from the Brazilian Federal Agency for Support and Evaluation of Graduate Education (CAPES), in the scope of the Program CAPES-PrInt, process number 88887.310463/2018-00, Mobility numbers \#88887.468939/2019-00 and \#88887.571230/2020-00. AR and RBJ also thanks "Conselho Nacional de Desenvolvimento Científico e Tecnológico (CNPq)" for research fellowships (grants \#305269/2018-6 and \#142396/2019-2).

Institutional Review Board Statement: Not applicable.

Informed Consent Statement: Not applicable.

Data Accessibility Statement: Data supporting the results in the paper are available in the Supplementary Material.

Acknowledgments: The authors would like to thank Caio Ambrosio Leal-Dutra, Celeste Heisecke, and Quimi Vidaurre Montoya for providing information from field observations. We also thank Salomé Urrea Valencia for depositing the voucher specimen at FLOR. We would like to thank the Center for Environmental Analysis and Planning (CEAPLA) of UNESP for providing climatic data. Basidiome drawings used in Figure 3A were created with BioRender.com. Lastly, we would like to thank the editor and four anonymous reviewers for their suggestions to improve the manuscript. Samples collected in Rio Claro, SP, Brazil were carried out under the ICMBio collecting permit \#31534-4 issued to AR. The study also complies with the Nagoya Protocol, under the SISGEn permit \# A24D9F2 issued to AR.

Conflicts of Interest: The authors have declared no conflict of interest. 


\section{References}

1. Branstetter, M.G.; Ješovnik, A.; Sosa-Calvo, J.; Lloyd, M.W.; Faircloth, B.C.; Brady, S.G.; Schultz, T.R. Dry habitats were crucibles of domestication in the evolution of agriculture in ants. Proc. Roy. Soc. B-Biol. Sci. 2017, 284, 20170095. [CrossRef]

2. Nygaard, S.; Hu, H.; Li, C.; Schiøtt, M.; Chen, Z.; Yang, Z.; Xie, Q.; Ma, C.; Deng, Y.; Dikow, R.B.; et al. Reciprocal genomic evolution in the ant-fungus agricultural symbiosis. Nat. Commun. 2016, 7, 12233. [CrossRef]

3. Schultz, T.R.; Brady, S.G. Major evolutionary transitions in ant agriculture. Proc. Natl. Acad. Sci. USA 2008, 105, 5435-5440. [CrossRef]

4. Bollazzi, M.; Roces, F. To build or not to build: Circulating dry air organizes collective building for climate control in the leaf-cutting ant Acromyrmex ambiguus. Anim. Behav. 2007, 74, 1349-1355. [CrossRef]

5. Bollazzi, M.; Roces, F. Leaf-cutting ant workers (Acromyrmex heyeri) trade off nest thermoregulation for humidity control. J. Ethol. 2010, 28, 399-403. [CrossRef]

6. Kleineidam, C.; Roces, F. Carbon dioxide concentrations and nest ventilation in nests of the leaf-cutting ant Atta vollenweideri. Insect. Soc. 2000, 47, 241-248. [CrossRef]

7. Wirth, R.; Herz, H.; Ryel, R.J.; Beyschlag, W.; Hölldobler, B. Herbivory of Leaf-Cutting Ants: A Case Study on Atta Colombica in the Tropical Rainforest of Panama (Vol. 164); Springer Science \& Business Media: Berlin/Heidelberg, Germany, 2002.

8. Cristiano, M.P.; Cardoso, D.C.; Sandoval-Gómez, V.E.; Simões-Gomes, F.C. Amoimyrmex Cristiano, Cardoso \& Sandoval, gen. nov. (Hymenoptera: Formicidae): A new genus of leaf-cutting ants revealed by multilocus molecular phylogenetic and morphological analyses. Austral. Entomol. 2020, 59, 643-676. [CrossRef]

9. $\quad$ Singer, R. The Agaricales in Modern Taxonomy, 4th ed.; Koeltz Scientific Books: Koenigstein, Germany, $1986 ;$ p. 981.

10. Corrêa, M.M.; Silva, P.S.; Wirth, R.; Tabarelli, M.; Leal, I.R. How leaf-cutting ants impact forests: Drastic nest effects on light environment and plant assemblages. Oecologia 2010, 162, 103-115. [CrossRef] [PubMed]

11. Meyer, S.T.; Leal, I.R.; Tabarelli, M.; Wirth, R. Ecosystem engineering by leaf-cutting ants: Nests of Atta cephalotes drastically alter forest structure and microclimate. Ecol. Entomol. 2011, 36, 14-24. [CrossRef]

12. Swanson, A.C.; Schwendenmann, L.; Allen, M.F.; Aronson, E.L.; Artavia-León, A.; Dierick, D.; Fernandez-Bou, A.S.; Harmon, T.C.; Murillo-Cruz, C.; Oberbauer, S.F.; et al. Welcome to the Atta world: A framework for understanding the effects of leaf-cutter ants on ecosystem functions. Funct. Ecol. 2019, 33, 1386-1399. [CrossRef]

13. Sternberg, L.D.S.; Pinzon, M.C.; Moreira, M.Z.; Moutinho, P.; Rojas, E.I.; Herre, E.A. Plants use macronutrients accumulated in leaf-cutting ant nests. Proc. Roy. Soc. B-Biol. Sci. 2007, 274, 315-321. [CrossRef]

14. Leal, I.R.; Oliveira, P.S. Interactions between fungus-growing ants (Attini), Fruits and Seeds in cerrado vegetation in southeast Brazil. Biotropica 1998, 30, 170-178. [CrossRef]

15. Farji-Brener, A.G.; Werenkraut, V. A meta-analysis of leaf-cutting ant nest effects on soil fertility and plant performance. Ecol. Entomol. 2015, 40, 150-158. [CrossRef]

16. Weber, N.A. Fungus-growing ants. Science 1966, 153, 587-604. [CrossRef]

17. Quinlan, R.J.; Cherrett, J.M. Aspects of the symbiosis of the leaf-cutting ant Acromyrmex octospinosus (Reich) and its food fungus. Ecol. Entomol. 1978, 3, 221-230. [CrossRef]

18. Chapela, I.H.; Rehner, S.A.; Schultz, T.R.; Mueller, U.G. Evolutionary history of the symbiosis between fungus-growing ants and their fungi. Science 1994, 266, 1691-1694. [CrossRef] [PubMed]

19. Mueller, U.G. Ant versus fungus versus mutualism: Ant-cultivar conflict and the deconstruction of the attine ant-fungus symbiosis. Am. Nat. 2002, 160, S67-S98. [CrossRef]

20. Möller, A. Die Pilzgärten Einiger Südamerikanischer Ameisen, 1st ed.; Verlag von Gustav Fischer: Jena, Germany, 1893; Volume 6, pp. 1-127.

21. Stahel, G.; Geijskes, D.C. Weitere Untersuchungen über den Nestbau und Gartenpilz von. Atta Cephalotes. Rev. Entomol. 1941, 12, 243-268.

22. Pagnocca, F.C.; Bacci, M., Jr.; Fungaro, M.H.; Bueno, O.C.; Hebling, M.J.; Sant'Anna, A.; Capelari, M. RAPD analysis of the sexual state and sterile mycelium of the fungus cultivated by the leaf-cutting ant Acromyrmex hispidus fallax. Mycol. Res. 2001, 105, 173-176. [CrossRef]

23. Autuori, M. Algumas observações sobre formigas cultivadoras de fungo (Hym. Formicidae). Rev. Bras. Entomol. 1940, 11, 215-226.

24. Muchovej, J.J.; Della Lucia, T.M.; Muchovej, R.M.C. Leucoagaricus weberi sp. nov. from a live nest of leaf-cutting ants. Mycol. Res. 1991, 95, 1308-1311. [CrossRef]

25. Fisher, P.J.; Stradling, D.J.; Pegler, D.N. Leaf cutting ants, their fungus gardens and the formation of basidiomata of Leucoagaricus Gongylophorus. Mycologist 1994, 8, 128-131. [CrossRef]

26. Fisher, P.J.; Stradling, D.J.; Pegler, D.N. Leucoagaricus basidiomata from a live nest of the leaf-cutting ant Atta cephalotes. Mycol. Res. 1994, 98, 884-888. [CrossRef]

27. Spielmann, A.A.; Putzke, J. Leucoagaricus gongylophorus (Agaricales, Basidiomycota) em ninho ativo de formigas Attini (Acromyrmex aspersus). Cad. Pesq. Sér. Botânica 1998, 10, 27-36.

28. Gonçalves, C.R. O gênero Acromyrmex no Brasil (Hym. Formicidae). Stud. Entomol. 1961, 4, 113-180.

29. Luederwaldt, H. Observações biológicas sobre formigas brasileiras especialmente do estado de São Paulo. Rev. Museu Paul. 1926, $14,185-303$. 
30. Heim, R. A propos du Rozites gongylophora A. Möller. Rev. Mycol. 1957, 22, 293-299.

31. Stahel, G. Sobre o fungo cultivado pela formiga Atta cephalotes L. An. Prim. Reun. Sul-Am. Bot. 1938, 1, $199-206$.

32. Stahel, G.; Geijskes, D.C. Ueber den bau der nester von Atta cephalotes L. und Atta sexdens L. (Hym. Formicidae). Rev. Entomol. 1939, 10, 27-78.

33. Stahel, G.; Geijskes, D.C. De parasolmieren en hunne bestrijding. Bull. Depart. Landbouw. 1940, 56, 1-26.

34. Baker, D.M.; Freeman, C.J.; Wong, J.C.; Fogel, M.L.; Knowlton, N. Climate change promotes parasitism in a coral symbiosis. ISME J. 2018, 12, 921-930. [CrossRef] [PubMed]

35. Brosi, G.B.; McCulley, R.L.; Bush, L.P.; Nelson, J.A.; Classen, A.T.; Norby, R.J. Effects of multiple climate change factors on the tall fescue-fungal endophyte symbiosis: Infection frequency and tissue chemistry. New Phytol. 2011, 189, 797-805. [CrossRef] [PubMed]

36. Ellis, C.J.; Coppins, B.J. Contrasting functional traits maintain lichen epiphyte diversity in response to climate and autogenic succession. J. Biogeogr. 2006, 33, 1643-1656. [CrossRef]

37. Kersch, M.F.; Fonseca, C.R. Abiotic factors and the conditional outcome of an ant-plant mutualism. Ecology 2005, 86, 2117-2126. [CrossRef]

38. Büntgen, U.; Egli, S.; Camarero, J.J.; Fischer, E.M.; Stobbe, U.; Kauserud, H.; Tegel, W.; Sproll, L.; Stenseth, N.C. Drought-induced decline in Mediterranean truffle harvest. Nat. Clim. Chang. 2012, 2, 827-829. [CrossRef]

39. Büntgen, U.; Egli, S.; Tegel, W.; Stobbe, U.; Sproll, L.; Elburg, R.; Peter, M.; Nievergelt, D.; Cherubini, P.; Stenseth, N.C. Illuminating the mysterious world of truffles. Front. Ecol. Environ. 2012, 10, 462-463. [CrossRef]

40. Costa, M.L.; 2021 URM-Herbário Pe. Camille Torrand. Version 1.84. Universidade Federal de Pernambuco. Available online: https:/ / www.gbif.org/ occurrence/2464956731 (accessed on 25 June 2021).

41. Ueda, K. 2021 iNaturalist Research-Grade Observations. Available online: https://www.gbif.org/occurrence/1986496332 (accessed on 25 June 2021).

42. Lacerda, L.T.; Gusmão, L.F.; Rodrigues, A. Diversity of endophytic fungi in Eucalyptus microcorys assessed by complementary isolation methods. Mycol. Prog. 2018, 17, 719-727. [CrossRef]

43. White, T.J.; Bruns, T.; Lee, S.J.W.T.; Taylor, J. Amplification and direct sequencing of fungal ribosomal RNA genes for phylogenetics. In PCR Protocols: A Guide to Methods and Applications; Innis, M.A., Gelfand, D.H., Sninsky, J.J., White, T.J., Eds.; Academic Press: San Diego, CA, USA, 1990; Volume 18, pp. 315-322.

44. Rehner, S.A.; Samuels, G.J. Taxonomy and phylogeny of Gliocladium analysed from nuclear large subunit ribosomal DNA sequences. Mycol. Res. 1994, 98, 625-634. [CrossRef]

45. Vilgalys, R.; Hester, M. Rapid genetic identification and mapping of enzymatically amplified ribosomal DNA from several Cryptococcus species. J. Bacteriol. 1990, 172, 4238-4246. [CrossRef]

46. Hall, T. BioEdit: A user-friendly biological sequence alignment editor and analysis program for Windows 95/98/NT. Nucleic Acids Symp. Ser. 1999, 41, 95-98.

47. RStudio Team. RStudio: Integrated Development Environment for R.; RStudio, PBC: Boston, MA, USA, 2021; Available online: http:/ / www.rstudio.com/ (accessed on 25 June 2021).

48. R Core Team. R: A Language and Environment for Statistical Computing.; R Foundation for Statistical Computing: Vienna, Austria, 2021; Available online: https:/ / www.R-project.org/ (accessed on 25 June 2021).

49. Wickham, H. Ggplot2: Elegant Graphics for Data Analysis; Springer: New York, NY, USA, 2016; ISBN 978-3-319-24277-4. Available online: https: / / ggplot2.tidyverse.org (accessed on 25 June 2021).

50. Kucheryavskiy, S. mdatools—R package for chemometrics. Chemom. Intell. Lab. Syst. 2020, 198, 103937. [CrossRef]

51. Mikheyev, A.S.; Mueller, U.G.; Abbot, P. Cryptic sex and many-to-one coevolution in the fungus-growing ant symbiosis. Proc. Natl. Acad. Sci. USA 2006, 103, 10702-10706. [CrossRef] [PubMed]

52. Butlin, R. The costs and benefits of sex: New insights from old asexual lineages. Nat. Rev. Genet. 2002, 3, 311-317. [CrossRef] [PubMed]

53. Koné, N.A.; Dosso, K.; Konaté, S.; Kouadio, J.Y.; Linsenmair, K.E. Environmental and biological determinants of Termitomyces species seasonal fructification in central and southern Côte d'Ivoire. Insect. Soc. 2011, 58, 371-382. [CrossRef]

54. Yang, X.; Luedeling, E.; Chen, G.; Hyde, K.D.; Yang, Y.; Zhou, D.; Xu, J.; Yang, Y. Climate change effects fruiting of the prize matsutake mushroom in China. Fungal Divers. 2012, 56, 189-198. [CrossRef]

55. Eveling, D.W.; Wilson, R.N.; Gillespie, E.S.; Bataille, A. Environmental effects on sporocarp counts over fourteen years in a forest area. Mycol. Res. 1990, 94, 998-1002. [CrossRef]

56. Krebs, C.J.; Carrier, P.; Boutin, S.; Boonstra, R.; Hofer, E. Mushroom crops in relation to weather in the southwestern Yukon. Botany 2008, 86, 1497-1502. [CrossRef]

57. Pecl, G.T.; Araújo, M.B.; Bell, J.D.; Blanchard, J.; Bonebrake, T.C.; Chen, I.C.; Clark, T.D.; Colwell, R.K.; Danielsen, F.; Evengård, B.; et al. Biodiversity redistribution under climate change: Impacts on ecosystems and human well-being. Science 2017, 355, eaai9214. [CrossRef]

58. Scheffers, B.R.; De Meester, L.; Bridge, T.C.; Hoffmann, A.A.; Pandolfi, J.M.; Corlett, R.T.; Butchart, S.H.; Pearce-Kelly, P.; Kovacs, K.M.; Dudgeon, D.; et al. The broad footprint of climate change from genes to biomes to people. Science 2016, 354, aaf7671. [CrossRef] 